\title{
RADIOFREQUENCY ABLATION IN ATRIAL TACHYCARDIA PAROXYSM ON EXAMPLE OF CLINICAL CASE
}

Brynza M. S. , Zaporiz'ka V. V. ${ }^{1}$, Vasylenko O. A. ${ }^{1}$, Volkov D. E. ${ }^{2}$

${ }^{1}$ V. N. Karazin Kharkiv National University, Kharkiv, Ukraine

${ }^{2}$ SI «Zaycev V.T. Institute of General and Urgent Surgery NAMS of Ukraine», Kharkiv, Ukraine

The disappearance of atrial tachycardia paroxysms after radiofrequency catheter ablation (RFA) of ectopic focus in a left atrium is presented on example of clinical case. Atrial tachycardia paroxysms disappeared after ablation completely.

KEY WORDS: atrial tachycardia paroxysms, radiofrequency catheter ablation

\section{РАДІОЧАСТОТНА АБЛЯЦІЯ ПРИ ПАРОКСИЗМІ ПЕРЕДСЕРДНОЇ ТАХІКАРДІЇ НА ПРИКЛАДІ КЛІНІЧНОГО ВИПАДКУ}

Бринза М. С. ${ }^{1}$, Запорізька В. В. ${ }^{1}$, Василенко О. О. ${ }^{1}$, Волков Д. $\epsilon^{2}$

${ }^{1}$ Харківський національний університет імені В. Н. Каразіна, м. Харків, Україна

${ }^{2}$ ДУ «Інститут загальної та невідкладної хірургії ім. В. Т. Зайцева НАМН України», м. Харків, Україна

Зникнення нападів передсердної тахікардії після виконання радіочастотної катетерної абляції (РЧА) ектопічного вогнища у лівому передсерді на прикладі клінічного випадку. Нападки передсердної тахікардії після абляції зникли зовсім.

КЛЮЧОВІ СЛОВА: напади передсердної тахікардії, радіочастотна катетерна абляція

\section{РАДИОЧАСТОТНАЯ АБЛЯЦИЯ ПРИ ПАРОКСИЗМЕ ПРЕДСЕРДНОЙ ТАХИКАРДИИ НА ПРИМЕРЕ КЛИНИЧЕСКОГО СЛУЧАЯ}

Брынза М. С. ${ }^{1}$, Запорожская В. В. ${ }^{1}$, Василенко О. А. ${ }^{1}$, Волков Д. Е. ${ }^{2}$

${ }^{1}$ Харьковский национальный университет имени В. Н. Каразина, г. Харьков, Украина

${ }^{2}$ ГУ «Институт общей и неотложной хирургии им. В.Т. Зайцева НАМН Украины», г. Харьков, Украина

Исчезновение приступов предсердной тахикардии после проведения радиочастотной катетерной абляции (РЧА) эктопического очага в левом предсердии на примере клинического случая. Приступы предсердной тахикардии после абляции исчезли полностью.

КЛЮЧЕВЫЕ СЛОВА: приступы предсердной тахикардии, радиочастотная катетерная абляция

\section{INTRODUCTION}

Atrial tachycardia accounts for approximately $20 \%$ of all supraventricular tachycardia [1]. Heart ablation is based on duplication or destruction of those tissues that provoke an irregular heartbeat [1-3]. Heart ablation is the most effective method of treatment, if the previous pharmacotherapy was not effective or it cannot be used due to side effects in the body [1-4].

(C) Brynza M. S., Zaporiz'ka V. V., Vasylenko O. A., Volkov D. E., 2018
Taking this into account, we present a clinical case that demonstrates the disappearance of atrial tachycardia paroxysms after radiofrequency catheter ablation (RFA).

\section{CLINICAL CASE}

54 years old woman, a resident of Donetsk region. Diagnosis during hospitalization: Permanent-recurring atrial tachycardia.

Complaints: shortness of breath, palpitation, diffuse headaches in a high blood pressure periods, dizziness, general weakness. 
Anamnesis morbi: patient suffers from hypertension for about 10 years (maximal blood pressure $(\mathrm{BP})=160 / 90 \mathrm{~mm} \mathrm{Hg}$ ). During the same time, heartbeat attacks, provoked by stress, nearly 1 time in 6 months, initially stopped independently during rest. Last 2 years heartbeat attacks became more frequent (every 3 months), which were stopped by antiarrhythmic drugs. On electrocardiogram (ECG) a supraventricular tachycardia with narrow QRS complexes, with rate of 140-160 per minute, $\mathrm{P}$ is not differentiated.

Medicinal therapy (regular cardiomagnil, irregularly bisoprolol) without effect. RFA intervention is recommended. Anamnesis vitae: carried diseases: angina in childhood, occasionally catarrhal diseases. Family history: patient notes hypertension and atrial fibrillation in her mother. She denies harmful habits. Tuberculosis, viral hepatitis, diabetes mellitus, sexually transmitted diseases, transfusion transmissibility is denied. Operations and injuries are denied too. Allergic history without peculiarities.

Objective status: general condition of moderate severity, consciousness is clear, position is active. Skin and visible mucous membranes are clean, pale pink. Thyroid gland: palpable isthmus. Mammary glands are symmetrical, without seals. Musculoskeletal system without peculiarities. There is pulmonary sound above the lungs, vesicular breathing, no crackles. The pulsation of neck vessels is not determined. Heart borders are within the normal range. Heart beats are rhythmic, the tones are muffled, I > II at the apex, on the basis of no accents, murmurs are not heeded, heart rate -66 beats/min. BP (right arm) $=130 / 80 \mathrm{~mm} \mathrm{Hg} ; \mathrm{BP}$ (left arm) $=125 / 80 \mathrm{~mm} \mathrm{Hg}$. The tongue is clean and moist. Belly palpation is soft, painless. The liver border is at arch edge, the spleen is not palpable. Pasternatsky's symptom is negative on both sides. Peripheral edema is absent.Tests results: in $\mathrm{CBC}$, urine and biochemical blood test without changes. ECG (January 31, 2017) before RFA: paroxysm of atrial tachycardia with heart rate 150 per min, vertical position of electric heart axis, left ventricular (LV) hypertrophy; ECG after RFA (01.02.2017) sinus rhythm, regular, with heart rate 72 per min, vertical position of electrical heart axis, LV hypertrophy. Holter monitoring before RFA: for monitoring time 23:54 rhythm disturbances were registrated - chronic permanent-recurring atrial tachycardia with short episodes of sinus rhythm, mainly at night with an average heart rate of 104 per min; minimal heart rate -60 per min at 03:28 during sleep, maximal heart rate -192 per min at 06:56 - during exercise. The circadian index is 1.46 (elevated). At echocardiography (Echo) (January 31, 2017): aorta and valves closure, mitral valve regurgitation of 1 degree, heart chambers are not dilated. The LV walls are not thickened. The LV systolic function satisfactory during severe tachycardia. Zones of local contractility violations are not localized. Right chambers are not dilated. Tricuspid regurgitation of 1 degree, ejection fraction (EF) - $61 \%$. Heart rate variability (HRV) was recorded at sinus rhythm before RFA (01.02.2017), it reflected the high total power (TP) of spectrum, and after RFA TP decreased by 5 times, but remains high, it indicating a slow humoral and metabolic type of regulation. 02.01.2017 RFA was performed - complete isolation of ectopic zone in the left atrium was performed. Clinical diagnosis: coronary artery disease: diffuse cardiosclerosis. Atrial recurrent tachycardia with successful ablation, with the disappearance of tachycardia paroxysms and restoration of cardiac rhythm. Arterial hypertension II st. 1 degree, cardiovascular risk is low. Heart failure I st., I functional class (FC) with preserved systolic function of LV. Our recommendations: cardiologist observation at the place of residence. Bisoprolol $5 \mathrm{mg}$ per day, in the morning, under the control of heart rate. Cardiomagnil $75 \mathrm{mg}$ per day, before sleeping for a long time. Phone visit (02.03.17): patient lives at the far distance from our center, which makes it impossible for her physical visit. A month later, after an RFA, patient reported heart rhythm disturbances, which were twice a month, lasted about 15-20 minutes and stopped at rest. The patient takes bisoprolol $5 \mathrm{mg} /$ day and cardiomagnil $75 \mathrm{mg} /$ day. Epilogue: at the moment when the article was completed, during the second telephone visit (04.04.17), patient did not mention disturbances of heart rhythm. Patient was advised to take bisoprolol $10 \mathrm{mg} /$ day. It is noted in literature that in acute postablative period there are possible rhythm disturbances with future recovery [5-6].

\section{CONCLUSIONS}

In this case, the RFA of atrial tachycardia was effective. The initial high total power of the HRV spectrum in the patient after ablation 
decreased by 5 times, but may predict rhythm disturbances in future. In pharmacotherapy, which included cardiomagnil and bisoprolol, the reduction in HRV suggested a gradual increase of the bisoprolol dose.

\section{REFERENCES}

1. Regular atrial tachycardia following pulmonary vein isolation for paroxysmal atrial fibrillation: a retrospective comparison between the cryoballoon and conventional focal tip radiofrequency techniques / [J. I. Juliá, G. B. Chierchia, C. de Asmundis et al]. // J Interv Card Electrophysiol. - 2015. - No. 42. P. 161-166.

2. Revishvili A. W. Hiryrgicheckyye i interventancionnyye podchodu k lecheniu ektopicheskoi predserdnoi tachikardii / A. W. Revishvili, G. S. Rashbaeva, S. Y. Serguladze. // Vestnik aritmologii. - 2011. - No. 6. - P. 53-55.

3. Yabluchanskiy M. I. Internal diseases: the time of global somatic risk / M. I. Yabluchanskiy, A. M. Yabluchanskiy, O. Y. Bychkova. // The Journal of V. N. Karazin Kharkiv National University. - 2013. No. 25. - P. 5-7.

4. Very long-term results of atrial fibrillation ablation confirm that this therapy is really effective / C.Tutuianu, J. Szilagy, R. Pap, L. Saghy. // J Atr Fibrillation. - 2015. - No. 8. - P. 1226.

5. Scheinman M. M. Patterns of catheter ablation practice in the United States / Scheinman. // Pacing Clin. Electrophysiol. - 1994. - No. 17. - P. 873-877.

6. Catheter ablation of atrial fibrillation in U.S. Community practice-results from outcomes registry for better informed treatment of atrial fibrillation (ORBIT-AF) / [F. Holmqvist, D. J. Simon, B. A. Steinberg та ін.]. // J Am Heart Assoc. - 2015. - No. 4. - P. e001901. 